\title{
Thoracoscopic bilateral sympathectomy for the treatment of hyperhidrosis: A complication of patient positioning
}

\author{
Hiperhidrozis tedavisinde torakoskopik bilateral sempatektomi: \\ Bir hasta pozisyonlama komplikasyonu \\ Emre Gedik ${ }^{1}$, Mehmet Hamdi Orum² ${ }^{10}$ \\ ${ }^{1}$ Department of Neurology, Kırklareli State Hospital, Kırklareli, Turkey \\ ${ }^{2}$ Department of Psychiatry, Adiyaman University Faculty of Medicine, Adiyaman, Turkey
}

\begin{abstract}
Severe palmar and/or axillary hyperhidrosis may adversely affect the patients. Thoracoscopic sympathectomy is frequently preferred for the treatment of severe hyperhidrosis. Patient positioning in surgery may cause a number of complications. In this article, we report a male patient who developed hypoesthesia on the palmar side of the first three fingers of the left hand after thoracoscopic bilateral sympathectomy for hyperhidrosis. Nerve conduction studies revealed non-significant results. Hypoesthesia was thought to be related to hyper-abduction position of arms. This complication disappeared two months after surgery. Appropriate patient positioning may prevent these complications.

Keywords: Complication, hyperhidrosis, hypoesthesia, patient positioning, sympathectomies.
\end{abstract}

öz

Şiddetli palmar ve/veya aksiller hiperhidrozis hastaları olumsuz etkileyebilir. Torakoskopik sempatektomi şiddetli hiperhidrozis tedavisinde sıklıkla tercih edilir. Cerrahide hasta pozisyonlaması bazı komplikasyonlara neden olabilir. Bu yazıda, hiperhidrozis için torakoskopik bilateral sempatektomi sonrası sol elin ilk üç parmağının palmar tarafında hipoestezi gelişen bir erkek hasta sunuldu. Sinir ileti çalışmaları anlamlı olmayan sonuçlar gösterdi. Hipoestezinin kolların hiper-abdüksiyon pozisyonu ile ilişkili olabileceği düşünüldü. Bu komplikasyon cerrahiden iki ay sonra ortadan kayboldu. Uygun hasta pozisyonlaması bu komplikasyonları önleyebilir.

Anahtar sözcükler: Komplikasyon, hiperhidrozis, hipoestezi, hasta pozisyonlaması, sempatektomiler.

Hyperhidrosis occurs as a result of increased sympathetic activity and may cause significant psychological problems and professional and social handicaps. ${ }^{[1]}$ Hasimoto et al. ${ }^{[2]}$ stated that actual prevalence of primary hyperhidrosis was $0.93 \%$ and nearly $50 \%$ of the respondents with primary hyperhidrosis reported impaired quality of life. Although treatments such as botulinum toxin type A, oral medication, topical therapy with aluminium chloride, psychotherapy, and iontophoresis are available, surgical sympathectomy is being increasingly utilized. Thoracoscopic sympathectomy (TS) is used in the treatment of palmar and/or axillary hyperhidrosis, Raynaud's phenomenon, and peripheral vascular insufficiency. ${ }^{[3-5]}$ Thoracoscopic sympathectomy is surgery to cut or clamp the sympathetic nerves and has complications such as pneumothorax, Horner syndrome, hemothorax, quilothorax, cubital nerve neuropraxia, and subcutaneous cervico-thoracic emphysema. ${ }^{[6]}$ In this case report, we discussed a 23-year-old male patient who was evaluated due

Received: December 25, 2018 Accepted: January 10, 2019 Published online: February 18, 2019

Correspondence: Mehmet Hamdi Orum. Adıyaman Üniversitesi Tıp Fakültesi, Psikiyatri Anabilim Dalı, 02100 Adıyaman, Turkey. Tel: +90 416 - 2161015 / 1186 e-mail: mhorum@hotmail.com 
to the hypoesthesia in the palmar side of the first three fingers of the left hand subsequent to TS for the treatment for hyperhidrosis.

\section{CASE REPORT}

A 23-year-old male patient was admitted to neurological outpatient clinic with the complaint of hypoesthesia of palmar side of first three fingers of left hand. According to the history, the patient had excessive sweating since high school. After starting university, social and psychological problems associated with excessive sweating increased. The treatments of iontophoresis and aluminium chloride failed. Thoracoscopic bilateral sympathectomy was planned and procedure of surgery included cutting thoracic ganglion 2, 3, 4 $\left(\mathrm{T}_{2}, \mathrm{~T}_{3}\right.$, and $\left.\mathrm{T}_{4}\right)$. Immediately after the operation, a hypoesthesia appeared on the left hand. Due to the continuation of hypoesthesia three days after surgery, he was admitted to thoracic surgery outpatient clinic and referred to our outpatient clinic. He had no trauma history after TS. His routine blood parameters, thyroid, kidney, and liver function tests were within normal limits. Chest X-ray and electrocardiogram gave normal results. The patient had no systemic disease or drug use. A history of smoking, alcohol, or substance abuse was not available. His family history was unremarkable. In the neurological examination, motor nerve function of left hand was normal. Sensory function of palmar side of the first and second fingers, and the palmar side of the phalanx distalis of the third finger were decreased (Figure 1). Nerve conduction

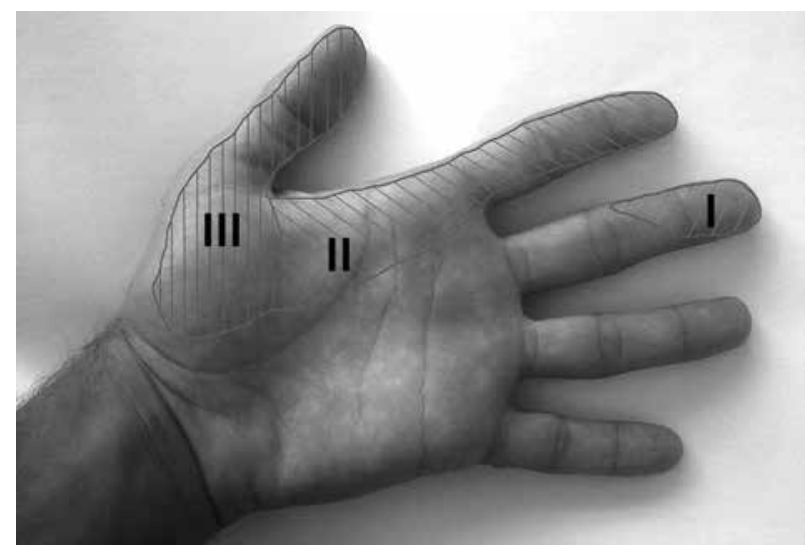

Figure 1. Demonstration of hypoesthesia areas on left hand. study on the $15^{\text {th }}$ day revealed non-significant results. On the $20^{\text {th }}$ day, the patient reported a reduction in the hypoesthesia of the third finger. Recovery continued from the third finger to the first finger. Hypoesthesia ceased two months after TS procedure. The hypoesthesia was attributed to hyper-abduction of arm, which is an operational positioning of TS surgery. No similar side effects were reported during the follow-up of the patient. A written informed consent was obtained from the patient.

\section{DISCUSSION}

This case presentation was evaluated as a case of hypoesthesia due to patient positioning. Other causes of hypoesthesia were excluded. Thoracoscopic sympathectomy is a surgical procedure in which a portion of sympathetic nerve trunk in the thoracic region is destroyed. Cautery use may cause operative complications. ${ }^{[6]}$ However, in our case, the hypoesthesia was related to the region which is stimulated by the median nerve. The median nerve is derived from the medial and lateral cords of the brachial plexus. It contains fibers from roots of cervical ganglion 6 (C6), $\mathrm{T}_{1}$, and may contain fibers from $\mathrm{C} 5$ in some individuals. Since the median nerve is located in an area over the operation region, hypoesthesia was not associated with the thermal effect of cautery. ${ }^{[1,7]}$ Patient positioning is another cause of operative nerve damage. The stretch sourced from hyper-abducted arm or any compression may have caused temporary hypoesthesia. ${ }^{[8]}$ Sensory fibers are located on the outer side of the nerves. For this reason, they are more prone to nerve damage. ${ }^{[9]}$ Therefore, physicians and relatives should be aware that patient positioning in TS may cause hypoesthesia.

\section{Declaration of conflicting interests}

The authors declared no conflicts of interest with respect to the authorship and/or publication of this article.

\section{Funding}

The authors received no financial support for the research and/or authorship of this article.

\section{REFERENCES}

1. Wohlrab J, Kreft B. Hyperhidrosis-aetiopathogenesis, diagnosis, clinical symptoms and treatment. Hautarzt 2018;69:857-69. [Abstract] 
2. Hasimoto EN, Cataneo DC, Reis TAD, Cataneo AJM. Hyperhidrosis: prevalence and impact on quality of life. J Bras Pneumol 2018;44:292-8.

3. Salim EF, Ali GA. Impact of Thoracoscopic T2 sympathectomy on patients with primary palmar and axillary hyperhidrosis. Ann Thorac Surg 2018;106:1032-7.

4. Bahar R, Zhou P, Liu Y, Huang Y, Phillips A, Lee $\mathrm{TK}$, et al. The prevalence of anxiety and depression in patients with or without hyperhidrosis $(\mathrm{HH})$. J Am Acad Dermatol. 2016;75:1126-33.

5. Gordon A, Zechmeister $\mathrm{K}$, Collin J. The role of sympathectomy in current surgical practice. Eur $\mathrm{J}$ Vasc Surg 1994;8:129-37.

6. Rodríguez PM, Freixinet JL, Hussein M, Valencia JM, Gil RM, Herrero J, et al. Side effects, complications and outcome of thoracoscopic sympathectomy for palmar and axillary hyperhidrosis in 406 patients. Eur J Cardiothorac Surg 2008;34:514-9.

7. Abe S, Tomita N, Yamamoto $\mathrm{M}$, Sato $\mathrm{M}$, Abe $\mathrm{H}$, Murakami G, et al. Topographical anatomy of the pronator teres muscle and median nerve: a study using histological sections of human fetuses. Okajimas Folia Anat Jpn 2017;94:37-44.

8. Wahlig JB Jr, Welch WC, Weigel TL, Luketich JD. Microinvasive transaxillary thoracoscopic sympathectomy: technical note. Neurosurgery 2000;46:1254-7.

9. Lundborg G, Dahlin LB. Anatomy, function, and pathophysiology of peripheral nerves and nerve compression. Hand Clin 1996;12:185-93. 